\title{
Performance of Large White and local pigs intensively reared in a tropical area in relation to nutritional conditions
}

\section{Rinaldot}

Institut National de la Recherche Agronomique, Station de Recherches Zootechniques, 97170 Petit Bourg, Guadeloupe, French West Indies

This report summarizes the results of research on pig production conducted for the last 25 years by the Institut National de la Recherche Agronomique in Guadeloupe ( $16^{\circ} \mathrm{N}, 61^{\circ} \mathrm{W}$, French West Indies). The experiments aimed to improve the utilization of nutritional and local genetic resources in an intensive rearing system. The use of starchy local foods such as banana, cassava and yams, for growing pigs was restricted by their chemical composition, in particular their high water content $(650$ to $800 \mathrm{~g} / \mathrm{kg})$ and their low protein content $(10$ to $30 \mathrm{~g} / \mathrm{kg})$. Moreover, the digestibility of the raw starch was found to be very low $(0.76$ to 0.83$)$ but it could be significantly improved by cooking. It was shown that 25 to $95 \mathrm{~kg}$ pigs given banana or cane molasses did not exhibit maximal daily weight gain even if the basal diet was supplemented with energy or protein. Assuming an average 0.15 proportional reduction in daily weight gain, compared with a maize-soya-bean meal diet, banana could be given ad libitum together with $1000 \mathrm{~g}$ of a supplementation diet providing $12.8 \mathrm{MJ}$ metabolizable energy and $250 \mathrm{~g}$ crude protein per $\mathrm{kg}$. Cane molasses could constitute up to $400 \mathrm{~g} / \mathrm{kg}$ diet provided that it was supplemented with protein and contained $360 \mathrm{~g} / \mathrm{kg}$ soya-bean meal. Local sows were 70 days younger at first farrowing than those of the Large White breed $(P<0.01)$. In contrast, litter size and piglet body weight at weaning were proportionately 0.11 $(P<0.05)$ and $0.51(P<0.01)$ higher in Large White sows than in local pigs, respectively. When given a well balanced pelleted diet, growing-finishing Large
White pigs exhibited a proportionately $0.17(P<0.01)$ higher daily weight gain and a $0.23(P<0.01)$ lower food: gain ratio than local pigs and had a leaner carcass $(P<0.01)$. Moreover, when pigs were given food ad libitum a diet with $500 \mathrm{~g} / \mathrm{kg}$ grass and $500 \mathrm{~g} /$ $\mathrm{kg}$ pelleted food, daily weight gain was proportionately 0.23 higher in Large White animals than in those of local breeds $(P<0.01)$ and the decrease in dry matter and nitrogen digestibility with the rise in dietary neutral-detergent fibre content was independent of genotype $(P>0.10)$. In pair-feeding conditions, the unfavourable effects of feeding a diet deficient in crude protein, which provided proportionately only 0.75 of the optimal crude protein level, were as pronounced in Large White as in local pigs but resulted in a $180 \mathrm{~g} / \mathrm{kg}$ higher daily weight gain $(P<0.01)$ and a leaner carcass $(P<0.05)$ in the former compared with the latter. In finishing pigs exposed to a tropical climate, compared with a 17 to $20^{\circ} \mathrm{C}$ ambient temperature, voluntary food intake and daily weight gain were decreased by proportionately $0.17(P<0.05)$ and 0.39 $(P<0.01)$, respectively, whereas food : gain ratio was increased by $0.30 \quad(P<0.05)$. Provision of shade improved daily weight gain and food : gain ratio by $0.10(P<0.01)$ and $0.08(P<0.01)$, respectively, in local growing-finishing pigs. The data thus showed that, in a tropical area, local pigs intensively reared exhibited lower growth performance than Large White animals and that both genotypes were as susceptible to poor nutritional conditions and to a tropical climate.
+ Present address: Institut National de la Recherche Agronomique, Station de Recherches Porcines, 35590 L'hermitage, France. 